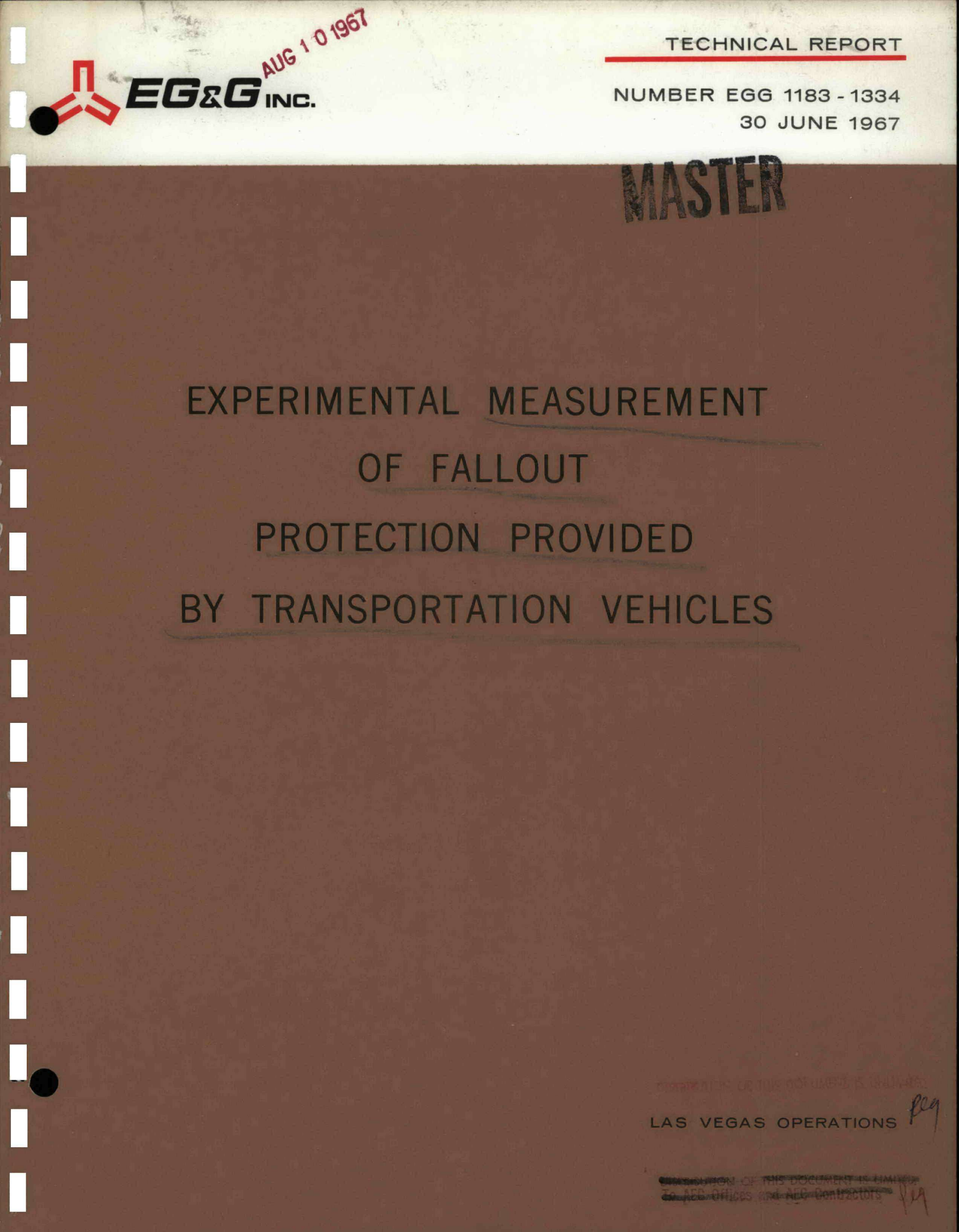




\section{DISCLAIMER}

This report was prepared as an account of work sponsored by an agency of the United States Government. Neither the United States Government nor any agency Thereof, nor any of their employees, makes any warranty, express or implied, or assumes any legal liability or responsibility for the accuracy, completeness, or usefulness of any information, apparatus, product, or process disclosed, or represents that its use would not infringe privately owned rights. Reference herein to any specific commercial product, process, or service by trade name, trademark, manufacturer, or otherwise does not necessarily constitute or imply its endorsement, recommendation, or favoring by the United States Government or any agency thereof. The views and opinions of authors expressed herein do not necessarily state or reflect those of the United States Government or any agency thereof. 


\section{DISCLAIMER}

Portions of this document may be illegible in electronic image products. Images are produced from the best available original document. 


\title{
EXPERIMENTAL MEASUREMENT OF FALLOUT PROTECTION PROVIDED BY TRANSPORTATION VEHICLES
}

\author{
By
}

R L. Summers

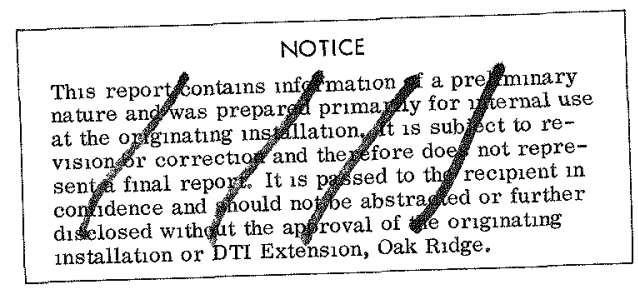

\section{LEGL NOTICE}

This report was prepared as an account of Government sponsored work. Neither the Unted States, nor the Commission, nor any person acting on behalf of the Commsasion

A Makes any warranty or representation, expressed or implied, with tespect to the accuracy, completeness, or usefulness of the information contaned $m$ this report, or that the use privately owned rights, or

B. Assumes any liabilities with respect to the use of, or for damages resulting from the use of any information, apparatus, method, or process disclosed in this report.

As used in the above, "person acting on behalf of the Commission" mncludes any employee or contractor of the Commission, or employee of such contractor, to the extent that such employee or contractor of the Commission, or employee of such contractor prepares, disseminates, or provides access to, any informatton pursuant to his employment or contract with the Commission, or his employment with such contractor.

Approved for Publication:

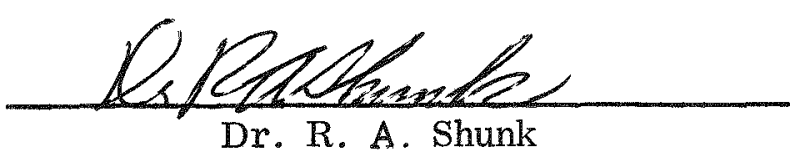

This Document is

UNCLASSIFIED

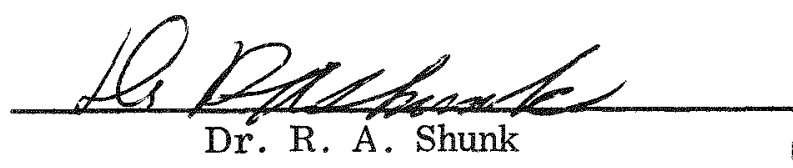




\section{CONTENTS}

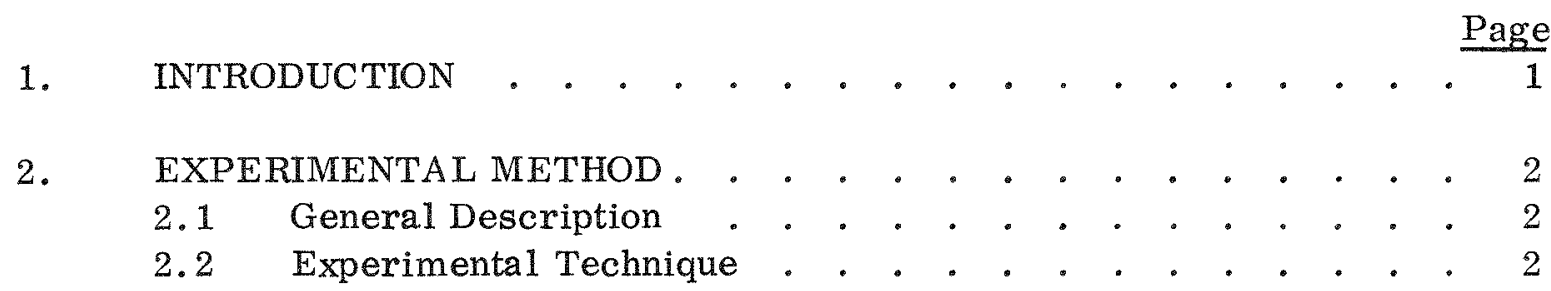

3. PRESENTATION OF DATA . . . . . . . . . . . . . 10

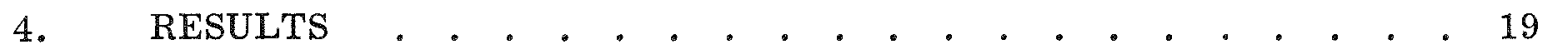

REFERENCES . . . . . . . . . . . . . . . . . . . 20

\section{TABLES}

Table

Page

1 Detector locations for types 4106 and 4107 vehicles (buses) . . . 3

2 Detector locations of typical school bus . . . . . . . . . . 4

3 Type 4106 vehicle . . . . . . . . . . . . . . . . 11

4 Type 4107 vehicle . . . . . . . . . . . . . . . . 12

5 School bus . . . . . . . . . . . . . . . . 13

6 Free-field measurements one meter above ground . . . . . . . 13

7 Information used in correcting and normalizing data . . . . . . 14 


\section{ILLUSTRATIONS}

Figure $\quad \underline{\text { Page }}$

1 Ground 1 tubing layout . . . . . . . . . . . . . 5

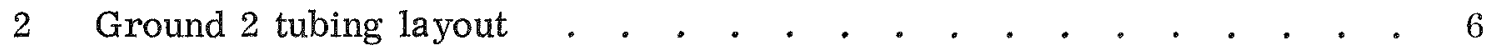

3 Type 4107 vehicle in position for the experiment . . . . . . . . 7

4 Typical seating arrangement and detector locations for types 4106 and 4107 vehicles . . . . . . . . . . . . . . 8

5 Typical seating arrangement and detector locations for the school bus . . . . . . . . . . . . . . . . . 9

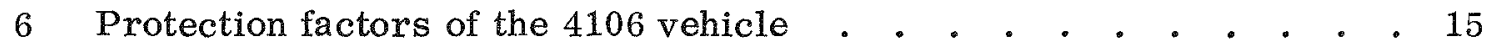

7 Protection factors of the 4107 vehicle.$\quad$. . . . . . . . . . 16

8 Protection factors of the school bus . . . . . . . . . . . . 17

9 Relative exposures, angular distribution at 1 meter for two ${ }^{60} \mathrm{Co}$ source configurations . . . . . . . . . . . . 18 


\section{INTRODUCTION}

The Civil Effects Test Operations (CETO) of the Division of Biology and Medicine (DBM) of the U. S. A tomic Energy Commission requested that experimental measurements be made of the fallout protection provided by transportation vehicles normally used to transport personnel.

The information will be useful for planning the possible evacuation of personnel from or through contaminated areas. 


\section{EXPERIMENTAL METHOD}

\subsection{GENERAL DESCRIPTION}

Measurements were made using the Mobile Radiological Measuring Unit (MRMU), a system which hydraulically pumps a ${ }^{60} \mathrm{Co}$ source through a length of tubing placed over the ground to simulate a uniform distribution of radioactivity. The measurements were conducted on a dry-lake bed at the Nevada Test Site.

Instrumentation for this experiment consisted of Victoreen condenser ion chambers which were previously calibrated with an NBS-calibrated ${ }^{\circ} \mathrm{Co}$ source.

Two ${ }^{60}$ Co sources were used from the MRMU system for simulating the fallout field. The activities of these sources were 418 millicuries and 113 curies, calibrated with NBS-calibrated Victoreen condenser R-chambers. Complete details of MRMU instrumentation and source calibrations are presented in Ref. 1 .

\subsection{EXPERIMENTAL TECHNIQUE}

The experimental technique consisted of creating simulated smooth planes of uniform contamination around the vehicles and measuring radiation levels at selected locations within. Three separate configurations were simulated, the results of which were used to obtain radiation levels (and thus protection factors) from a smooth, infinite plane of ${ }^{50} \mathrm{Co}$ contamination. These three configurations were:

1. First close-in ground contribution (Ground 1)

2. Second close-in ground contribution (Ground 2)

3. Far-out ground contribution (Ground FO)

The tubing was laid as uniformly as possible with a 1 -meter separation between tubes out to an effective radius of 7 meters for the Ground 1 contribution, shown in Fig. 1. For the Ground 2 contribution, the tubing was laid in an effective radius of from 7 to 21 meters, with a tubing separation of two meters (see Fig. 2). Figure 3 shows a photograph of a type 4107 vehicle in position on the tubing distribution. To provide experimental data as a basis for estimating the far-out ground contribution (contribution from contamination beyond close-in measurement areas), a ring source of a 100-meter radius was used.

Detector locations are described and physical locations are listed in Tables 1 and 2. Floor plans and detector locations are shown in Figs. 4 and 5 . 
Table 1. Detector locations for types $4106^{*}$ and $4107^{*}$ vehicles (buses).

Test

Designation Description

L1.1 Driver's seat (bottom)**

L1.2 Driver's seat (top)**

L2.1 1st seat on left behind driver (bottom)

L3.1 5th seal on left (bottom); also center seat of bus

L3.2 5th seat on left (top); also center seat of bus

L4.1 9th seat on left (bottom)

L5.1 Rear seat (bottom)

L5.2 Rear seat (top)

R1.1 1st seat on right (bottom)

R1.2 1st seat on right (top)

R2.1 2nd seat on right (bottom)

R3.1 5th seat on right (bottom); also center seat of bus

R3.2 5th seat on right (top); also center seat of bus

R4.1 7th seat on right (bottom)

R5.1 9th seat on right (bottom)

R5.2 9th seat on right (top)

C-1 $\quad 0.3$ meter above floor, geometric center of bus

C-2 1 meter above floor, geometric center of bus

C $-3 \quad 2$ meters above floor, geometric center of bus

*Type 4106 is the manufacturer's designation of the type of bus now in use at NTS. Type 4107 is the manufacturer's designation of the typical "Scenic Cruiser" bus, which will eventually replace the type 4106 bus at NTS.

**Bottom refers to lower abdomen. Top refers to chest area. 
Table 2. Detector locations of typical school bus.

Test

Designation

Description

L1

L2

L3

$\mathrm{L} 4$

L.5

L6

R1

$\mathrm{R} 2$

R3

$\mathrm{R} 4$

R5

$\mathrm{C}-1$

$\mathrm{C}-2$

$\mathrm{C}-3$
Driver's seat (top)*

1st seat on left behind driver (top)

$3 \mathrm{rd}$ seat on left (top)

4 th seat on left (top)

5 th seat on left (top)

7 th seat on left (top); also rear seat

1st seat on right (top)

3 rd seat on right (top)

4 th seat on right (top)

5 th seat on right (top)

7th seat on right (top); also rear seat

0.3 meter above floor, geometric center of bus

1 meter above floor, geometric center of bus

2 meters above floor, geometric center of bus

*Top refers to chest area.

At each location two dosimeters were placed in paper cups and taped in position to the seats and/or the backs of the seats of each vehicle. The average reading of dosimeters placed at one location was taken as the exposure at that location. The time of exposure varied from 10 minutes to 1 hour.

For each ground contribution, the following general procedures were observed:

1. All detectors were charged and placed in position while a dummy source capsule was pumped through the tubing to assure that it had not been damaged and to make sure that there were no restrictions to prevent the actual source from maintaining constant speed throughout the experimental tubing layout.

2. After radiological safety clearance was given, the hydraulic system was energized and an experimental run was made. After the test exposure, the source was secured in its shield, detectors were read, and readings were recorded. Temperature, pressure, and source exposure time were also recorded.

The experiment consisted of four phases: (1) free-field measurement, (2) vehicle type 4106 , (3) vehicle type 4107 , and (4) a school bus. 


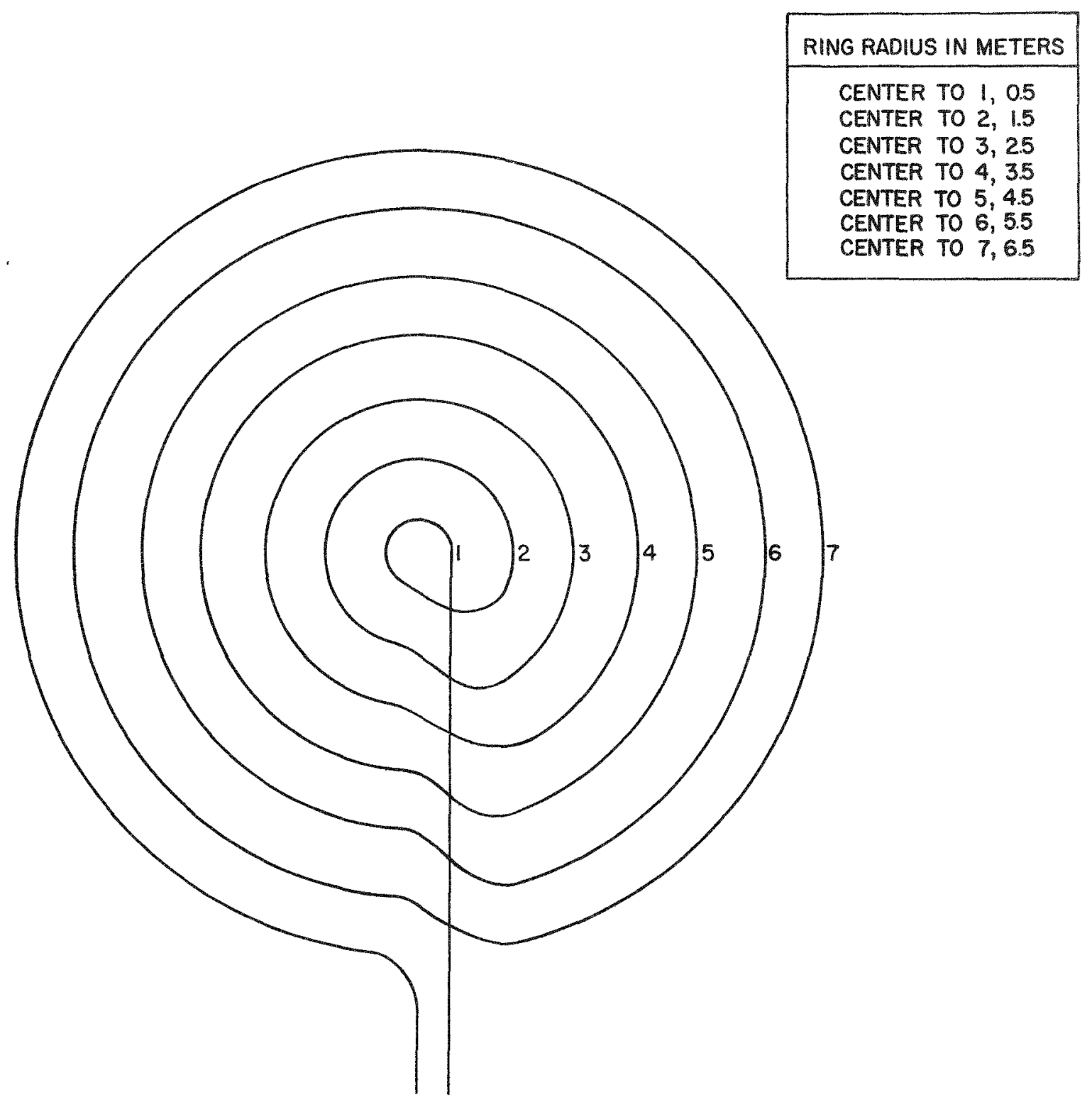

Fig. 1. Ground 1 tubing layout. 


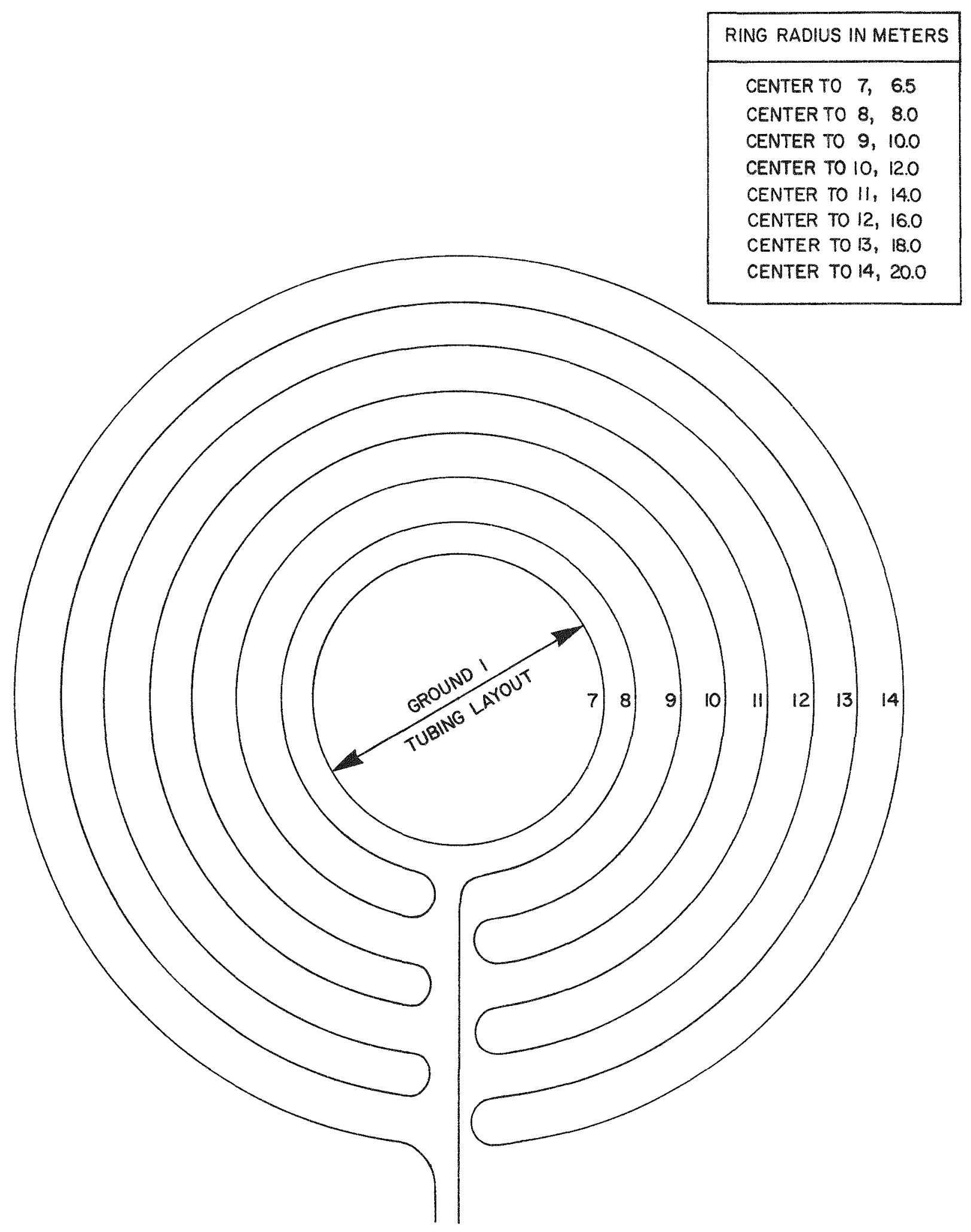

Fig. 2. Ground 2 tubing layout. 


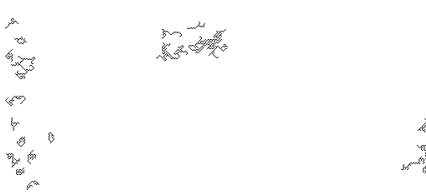

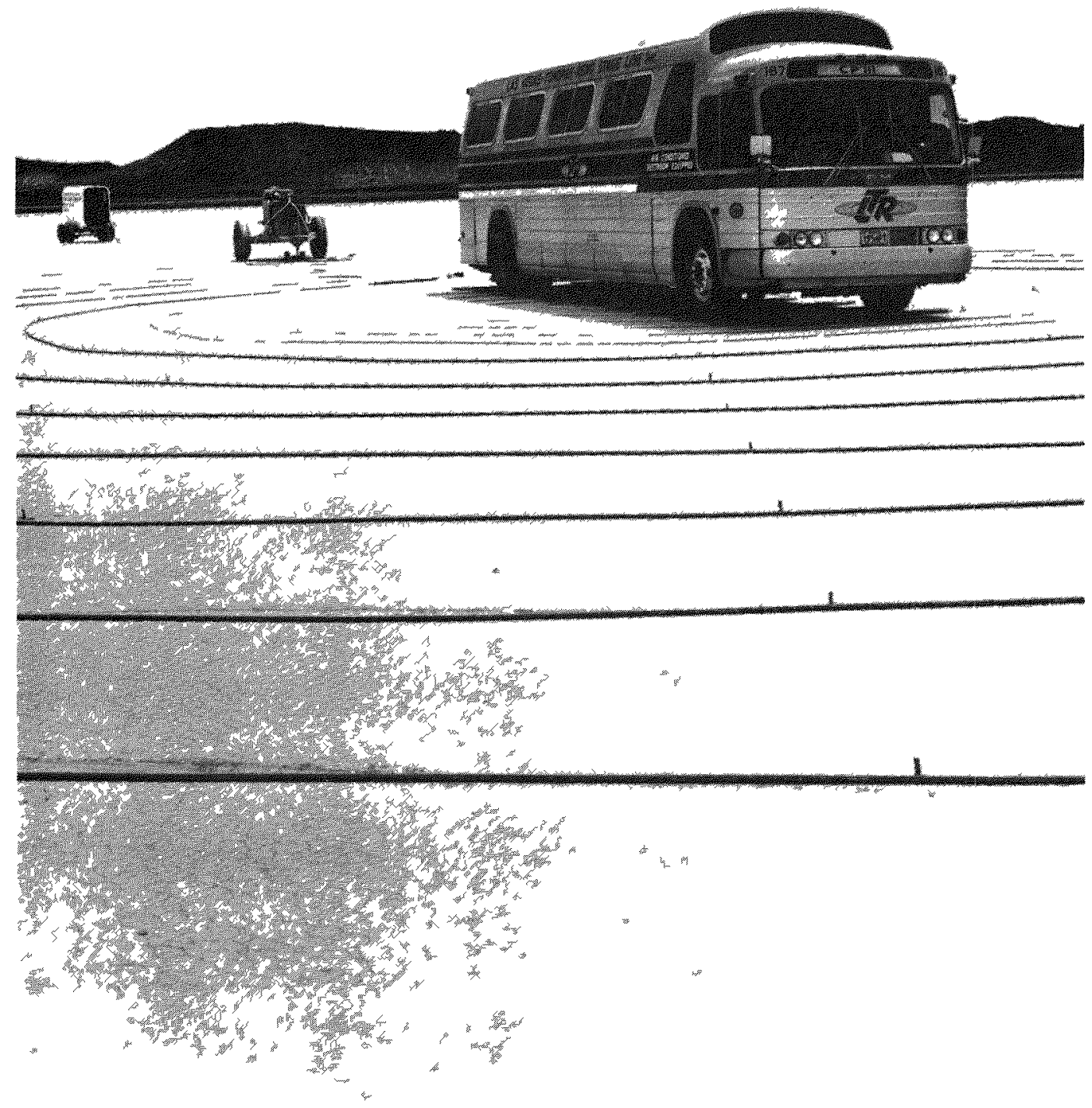

Fig. 3. Type 4107 vehicle in position for the experıment. 


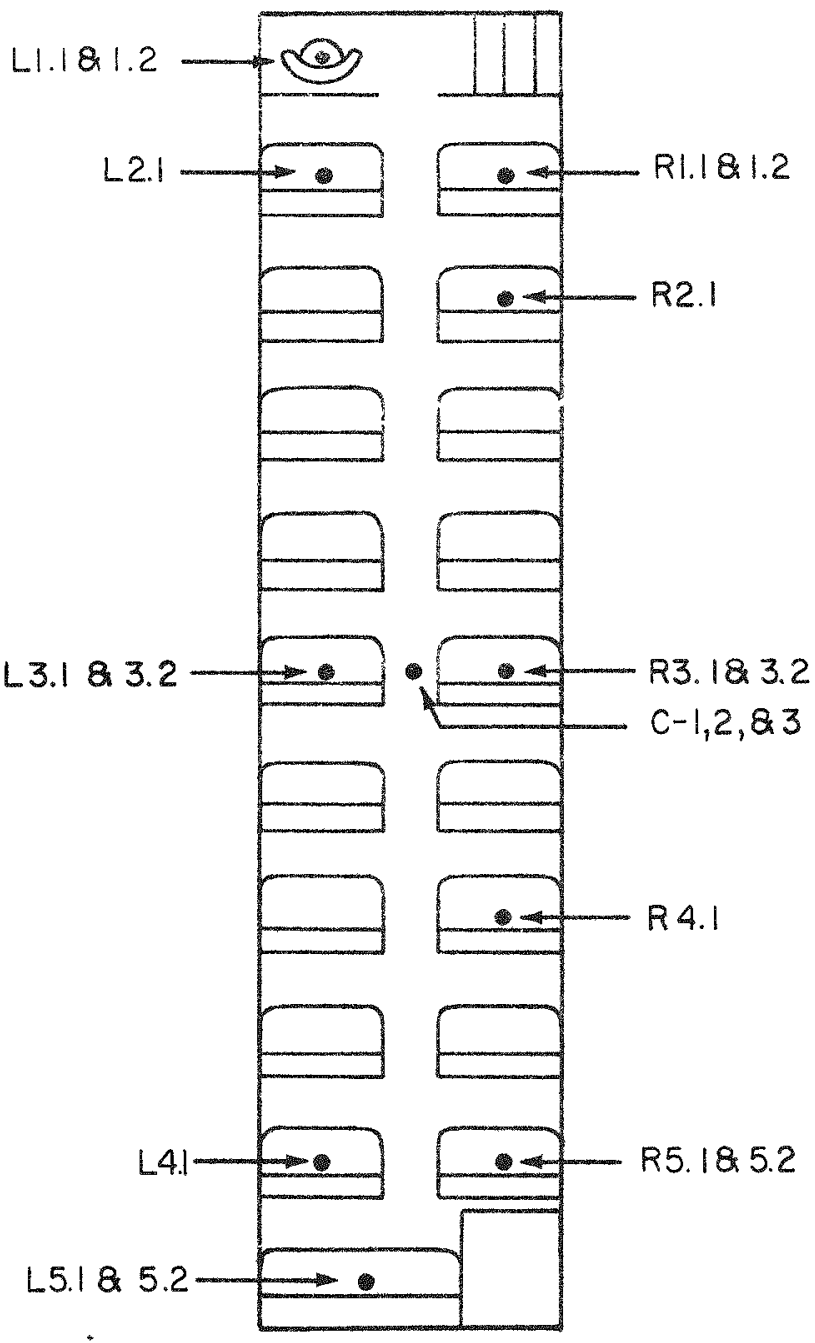

Fig. 4. Typical seating arrangement and detector locations for types 4106 and 4107 vehicles. 


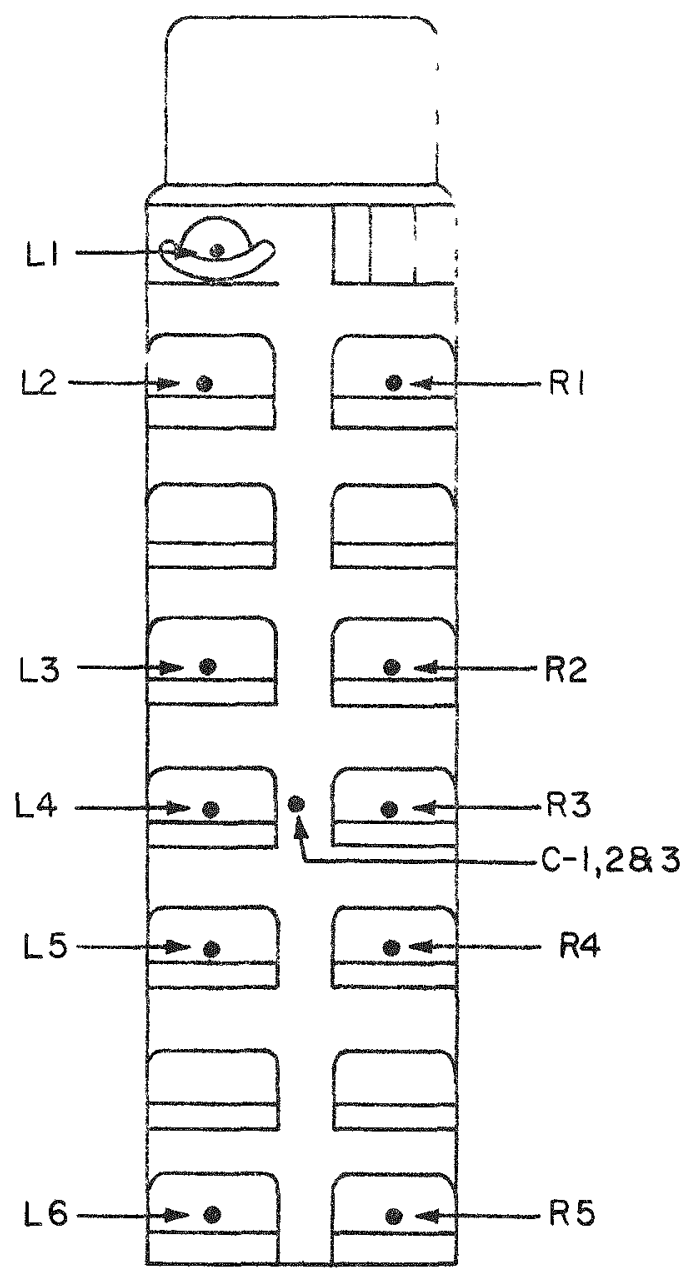

Fig. 5. Typical seating arrangement and detector locations for the school bus. 


\section{PRESENTATION OF DATA}

All normalized data appear in Tables 3, 4, 5, and 6; all input data for the normalized data appear in Table 7. Data plotted on floor plans are shown in Figures 6,7 , and 8 . The raw input data were averaged and then corrected for calibration, temperature and pressure, and source-exposure time and then normalized to a standard source density according to the equation

$$
E_{n}=\frac{E c \times A}{T \times S}
$$

where $\mathrm{E}_{\mathfrak{n}}=$ normalized exposure rate in $\mathrm{mr} / \mathrm{hr}$ per $\mathrm{mc} / \mathrm{sq}$ meter

$\mathrm{E}_{\mathrm{c}}=$ average corrected detector response in $\mathrm{mr}$

$\mathrm{A}=$ total area of contamination in sq meters

$\mathrm{T}=$ exposure time in hours

$\mathrm{S}=$ source activity in millicuries

These normalized data appear in the Ground 1 and Ground 2 data columns. The Ground far-out (FO) column refers to the contribution from contamination beyond the close-in measurement areas. This contribution was estimated by experimental data from a ring source at a 100-meter radius and free-field (no vehicle) exposure. The equation used to estimate the far-out contribution was

$$
\text { Ground } \mathrm{FO}=\frac{\mathrm{D}_{\mathrm{e}} \times \mathrm{E}_{\mathrm{m}}}{\mathrm{I}_{\mathrm{c}}}
$$

where Ground FO = far-out ground contribution (mr/hr per mc/sq metex) to a particular point in the vehicle

$\mathrm{Dc}_{\mathrm{c}}=$ free-field exposure $\mathrm{rate}(\mathrm{mr} / \mathrm{hr}$ per $\mathrm{mc} / \mathrm{sq}$ meter $)$ at 1 meter above ground from contamination beyond the close-in measurement area

$E_{\text {II }}=$ measured exposure rate $(\mathrm{mr} / \mathrm{hr}$ per $\mathrm{mc} / \mathrm{meter}$ of circumference) at the point in question from a ring source at a 100-meter radius

Ic $=$ measured free-field exposure $\mathrm{ring}(\mathrm{mr} / \mathrm{hr}$ per $\mathrm{mc} / \mathrm{meter}$ of circumference) 1 meter above ground from a ring source at a $100-$ meter radius 
Equation 2 can apply if the energy and angular distribution of $D_{c}$ are the same as Is. Figure $9^{*}$ shows that with the source geometries used in this experiment, errors are expected to be negligible. The value of $D_{c}$ was taken to be $14.35 \mathrm{mr} / \mathrm{hr}$ per $\mathrm{mc} / \mathrm{sq}$ meter. Do was taken as $44.8 \mathrm{mr} / \mathrm{hr}$ per $\mathrm{mc} / \mathrm{sq} \mathrm{m}$ (derived from a series of both theoretical and experimental determinations of the free-field infinite plane exposure rate). See for instance Ref. 2. Ic was measured and the value was $0.0613 \mathrm{mr} / \mathrm{hr}$ per mc/meter of circumference.

Table 3. Type 4106 vehicle.

\begin{tabular}{lrrrrr}
\hline Position & Ground 1 & Ground 2 & Ground FO & Total Ground & PF \\
\hline L1.1 & 2.79 & 8.61 & 9.90 & 21.30 & 2.1 \\
L1.2 & 7.28 & 9.26 & 14.81 & 31.35 & 1.4 \\
L2.1 & 6.76 & 8.93 & 10.74 & 26.43 & 1.7 \\
L3.1 & 9.96 & 6.80 & 10.06 & 26.82 & 1.7 \\
L3.2 & 8.91 & 7.46 & 11.44 & 27.81 & 1.6 \\
L4.1 & 6.21 & 6.63 & 9.34 & 22.18 & 2.0 \\
L5.1 & 5.70 & 8.43 & 8.49 & 22.62 & 2.0 \\
L5.2 & 7.54 & 11.90 & 10.93 & 30.37 & 1.5 \\
& & & & & \\
R1.1 & 6.62 & 8.11 & 10.20 & 24.93 & 1.8 \\
R1.2 & 5.85 & 8.76 & 12.03 & 26.64 & 1.7 \\
R2.1 & 9.52 & 7.10 & 10.46 & 27.08 & 1.7 \\
R3.1 & 11.14 & 6.63 & 10.06 & 27.83 & 1.6 \\
R3.2 & 8.24 & 7.63 & 11.44 & 27.31 & 1.6 \\
R4.1 & 10.07 & 10.27 & 9.80 & 30.14 & 1.5 \\
R5.1 & 6.10 & 6.12 & 9.34 & 21.56 & 2.1 \\
R5.2 & 4.93 & 7.96 & 11.65 & 24.54 & 1.8 \\
& & & & & \\
C-1 & 11.25 & 7.46 & 9.97 & 28.68 & 1.6 \\
C-2 & 8.60 & 7.43 & 12.14 & 28.37 & 1.6 \\
C-3 & 6.88 & 9.11 & 13.64 & 29.63 & 1.5 \\
\hline
\end{tabular}

*Unpublished data to be published later as CEX-63.8. 
Table 4. Type 4107 vehicle.

\begin{tabular}{lrrrrr}
\hline Position & Ground 1 & Ground 2 & Ground FO & Total Ground & PF \\
\hline L1.1 & 5.61 & 9.18 & 10.06 & 24.85 & 1.8 \\
L1.2 & 5.54 & 10.02 & 11.70 & 27.26 & 1.6 \\
L2.1 & 6.54 & 8.31 & 9.36 & 24.21 & 1.9 \\
L3.1 & 9.02 & 7.37 & 10.30 & 26.69 & 1.7 \\
L3.2 & 7.47 & 8.68 & 11.70 & 27.85 & 1.6 \\
L4.1 & 5.66 & 7.88 & 10.30 & 23.84 & 1.9 \\
L5.1 & 4.43 & 8.93 & 10.30 & 23.66 & 1.9 \\
L5.2 & 4.85 & 9.47 & 11.93 & 26.25 & 1.7 \\
& & & & & \\
R1.1 & 6.47 & 8.46 & 9.59 & 24.52 & 1.8 \\
R1.2 & 6.27 & 9.44 & 11.93 & 27.64 & 1.6 \\
R2.1 & 6.20 & 7.80 & 10.30 & 24.30 & 1.8 \\
R3.1 & 8.89 & 7.01 & 10.30 & 26.20 & 1.7 \\
R3.2 & 7.33 & 7.33 & 11.70 & 27.36 & 1.6 \\
R4.1 & 8.60 & 7.15 & 10.33 & 26.08 & 1.7 \\
R5.1 & 6.10 & 7.62 & 10.76 & 24.48 & 1.8 \\
R5.2 & 5.88 & 8.71 & 11.70 & 26.29 & 1.7 \\
& & & & & \\
C-1 & 10.30 & 7.48 & 8.42 & 26.20 & 1.7 \\
C-2 & 8.09 & 8.49 & 11.93 & 28.51 & 1.6 \\
C-3 & 6.30 & 7.95 & 13.10 & 27.35 & 1.6 \\
& & & & & \\
\hline
\end{tabular}


Table 5. School bus.

\begin{tabular}{lccccc}
\hline Position & Ground 1 & Ground 2 & Ground FO & Total Ground & PF \\
\hline L1 & 7.61 & 6.91 & 9.85 & 24.37 & 1.8 \\
L2 & 8.65 & 7.23 & 12.11 & 27.99 & 1.6 \\
L3 & 9.40 & 7.54 & 12.31 & 29.25 & 1.5 \\
L4 & 8.88 & 7.36 & 12.18 & 28.42 & 1.6 \\
L5 & 8.82 & 7.57 & 12.25 & 28.64 & 1.6 \\
L6 & 8.60 & 8.78 & 12.11 & 29.49 & 1.5 \\
& & & & & \\
R1 & 8.38 & 7.50 & 12.21 & 28.09 & 1.6 \\
R2 & 9.17 & 7.50 & 12.09 & 28.76 & 1.6 \\
R3 & 8.97 & 7.40 & 12.25 & 28.62 & 1.6 \\
R4 & 8.78 & 7.80 & 12.09 & 28.67 & 1.6 \\
R5 & 8.40 & 9.04 & 12.40 & 29.84 & 1.5 \\
& & & & & \\
C-1 & 10.75 & 6.47 & $12^{*}$ & 29.22 & $1.5 *$ \\
C-2 & 9.15 & 7.71 & $12^{*}$ & 28.86 & $1.6^{*}$ \\
C-3 & 7.76 & 8.65 & $12^{*}$ & 28.41 & $1.6^{*}$
\end{tabular}

*Estimated values.

Table 6. Free-field measurements one meter above ground.

\begin{tabular}{lccccc}
\hline Position & Ground 1 & Ground 2 & Total Close-in & Ground FO & Total \\
\hline 1 meter & 19.95 & 10.50 & 30.45 & $14.35^{*}$ & $44.8 *$
\end{tabular}

$*_{14.35}=44.8-30.45$. All values in this table have units of $\mathrm{mr} / \mathrm{hr}$ per $\mathrm{mc} / \mathrm{sq}$ meter. 
Table 7. Information used in correcting and normalizing data.

\begin{tabular}{|c|c|c|c|c|c|c|}
\hline $\begin{array}{l}\text { Data in } \\
\text { Table No. }\end{array}$ & $\begin{array}{l}\text { Type of } \\
\text { Run }\end{array}$ & $\begin{array}{l}\text { Exposure } \\
\text { Time (Hrs) }\end{array}$ & $\begin{array}{l}\text { Average } \\
\text { Temp }\left({ }^{\circ} \mathrm{C}\right)\end{array}$ & $\begin{array}{l}\text { Average } \\
\text { Pressure } \\
\text { (mm Hg) }\end{array}$ & $\begin{array}{l}\text { Area } \\
(\mathrm{Sq} \mathrm{m})\end{array}$ & $\begin{array}{l}\text { Source } \\
\text { Activity } \\
\text { (Curies) }\end{array}$ \\
\hline 3 & Ground 1 & 0.21 & 22 & 655 & 154 & 0.418 \\
\hline 3 & Ground 1 & 0.147 & 22 & 650 & 154 & 0418 \\
\hline 3 & Ground 2 & 0.482 & 23.5 & 655 & 1234 & 0.418 \\
\hline 3 & Ground FO & 0.298 & 28 & 655 & $628.3 \mathrm{~m}$ & 113.0 \\
\hline 3 & Ground FO & 0.301 & 28 & 655 & $628.3 \mathrm{~m}$ & 113.0 \\
\hline 4 & Ground 1 & 0.17 & 35 & 655 & 154 & 0.418 \\
\hline 4 & Ground 2 & 1.086 & 34 & 655 & 1234 & 0.418 \\
\hline 4 & Ground FO & 0.642 & 32 & 655 & $628.3 \mathrm{~m}$ & 113.0 \\
\hline 5 & Ground 1 & 0.185 & 40 & 655 & 154 & 0.418 \\
\hline 5 & Ground 2 & 1.01 & 36 & 655 & 1234 & 0.418 \\
\hline 5 & Ground FO & 0.643 & 31 & 655 & $628.3 \mathrm{~m}$ & 113.0 \\
\hline 6 & Ground 1 & 0.18 & 35 & 655 & 154 & 0.418 \\
\hline 6 & Ground 2 & 0.806 & 34 & 655 & 1234 & 0.418 \\
\hline 6 & Ground $\mathrm{FO}$ & 0.336 & 37 & 655 & $628.3 \mathrm{~m}$ & 113.0 \\
\hline
\end{tabular}




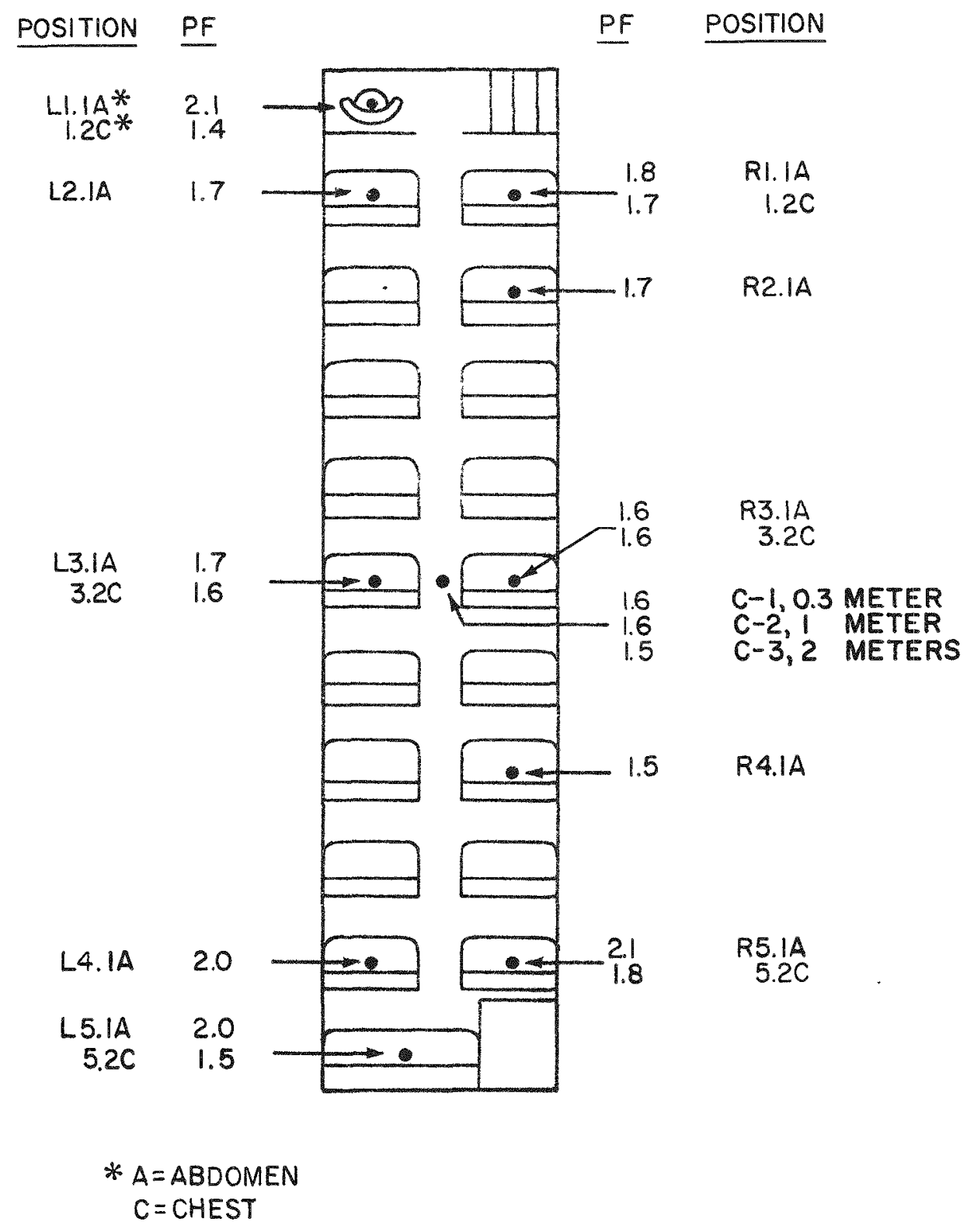

Fig. 6. Protection factors of the 4106 vehicle. 


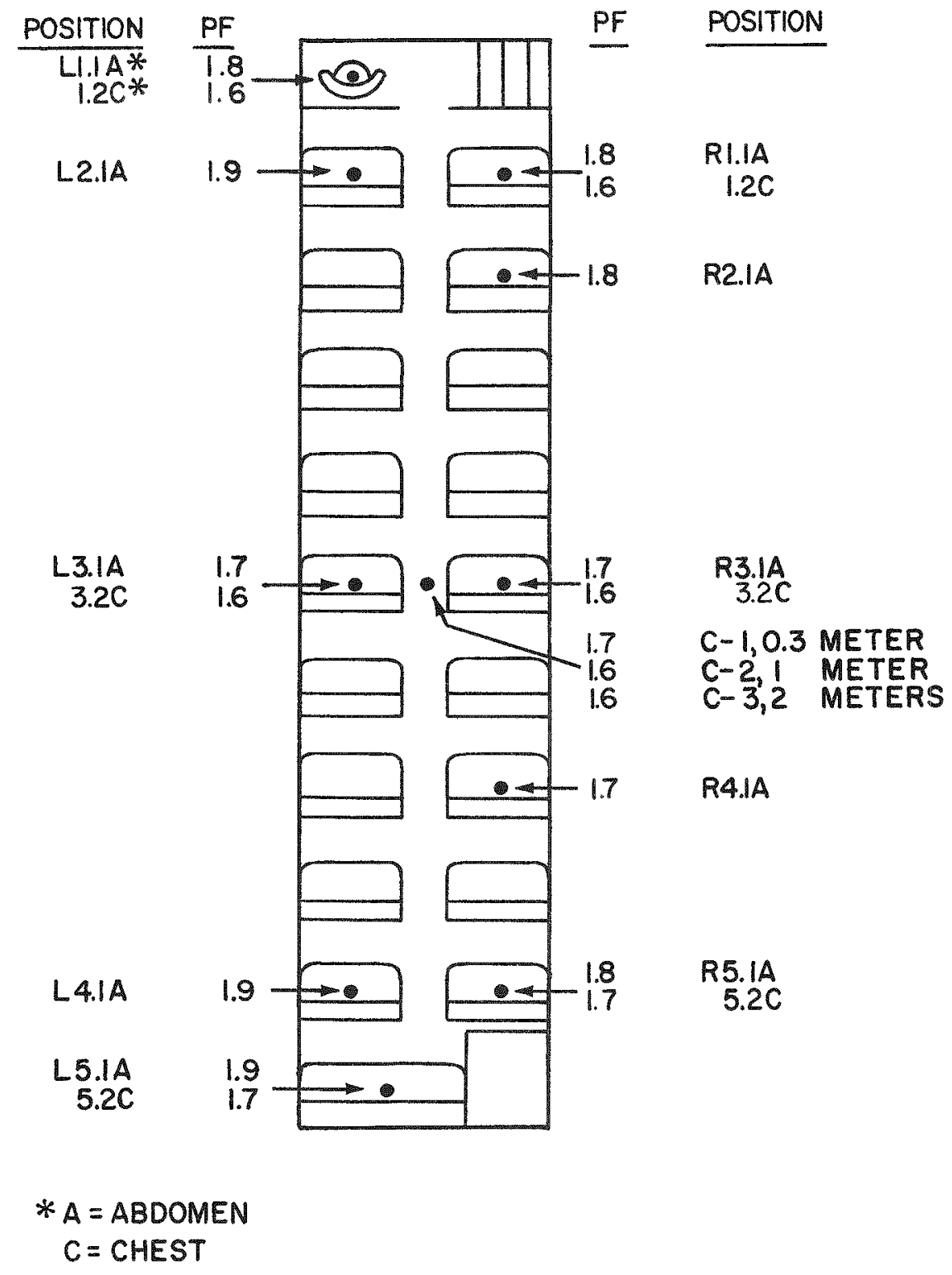

Fig. 7. Protection factors of the 4107 vehicle. 


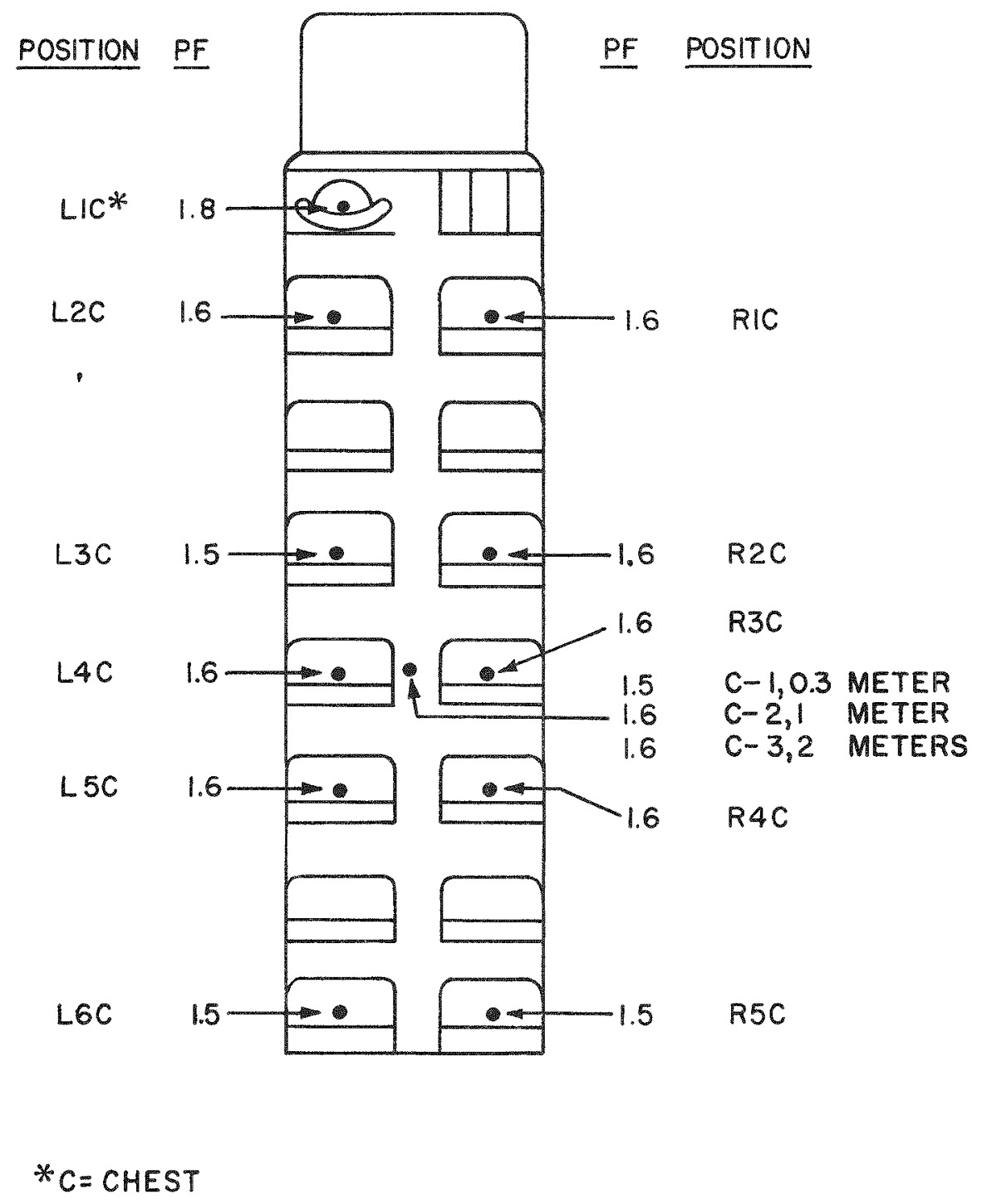

Fig. 8. Protection factors of the school bus. 


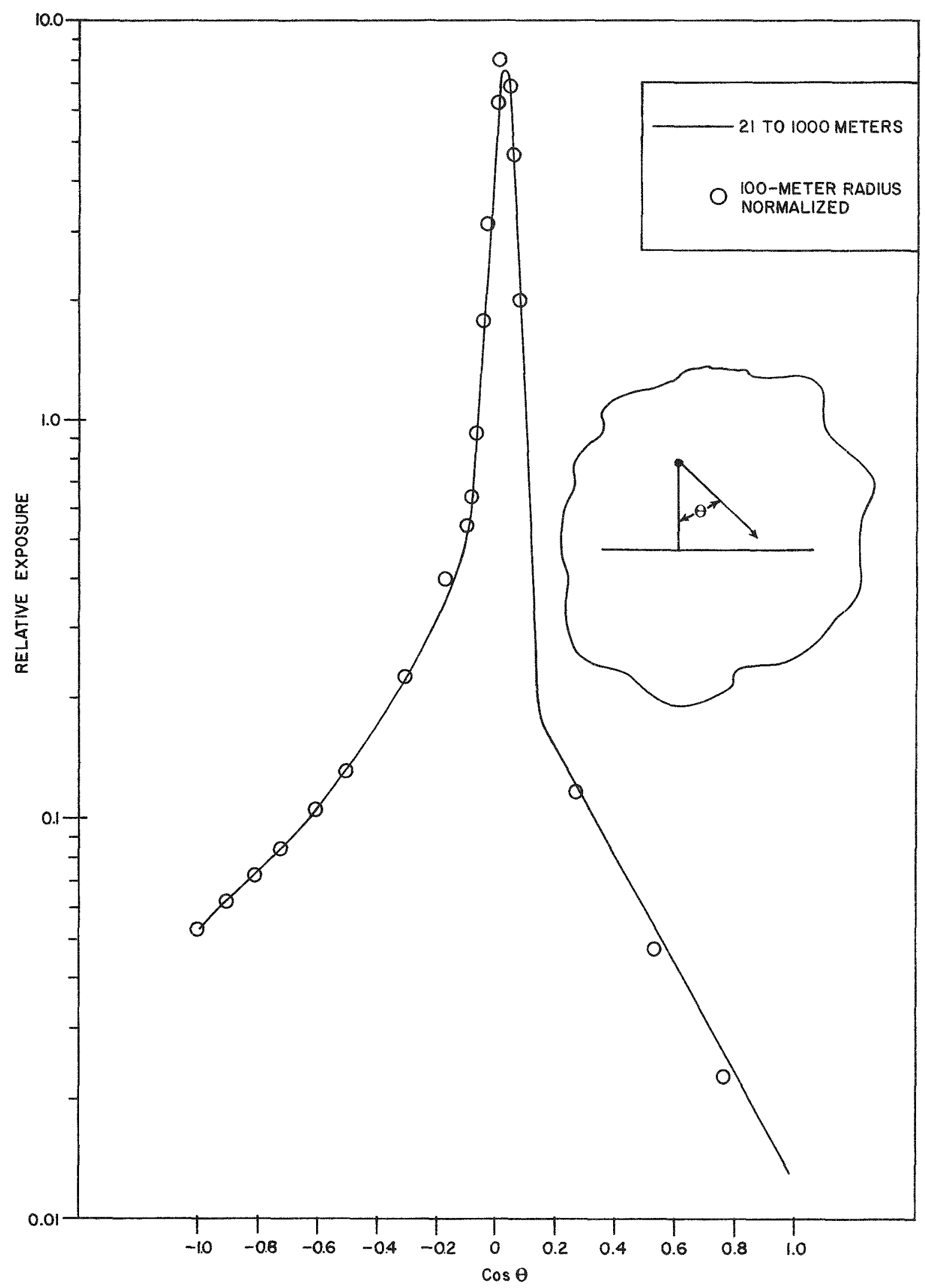

Fig. 9. Relative exposures, angular distribution at 1 meter for two ${ }^{60} \mathrm{Co}$ source configurations. 


\section{RESULTS}

To evaluate the protective qualities of a vehicle and to give the protection quantitative expression, the term protection factor (PF) is used. This is a number indicating the protective value of a vehicle, and it provides a measure of how much less the radiation level would be at a given point inside the vehicle than outside in an unprotected area. In technical terms it is the ratio of the exposure-rate one meter above a smooth infinite plane uniformly contaminated with radioactive material to the exposure rate at a specific point in question, assuming the same source distribution. Accordingly,

$$
\mathrm{PF}=\frac{\mathrm{D}_{\infty}}{\mathrm{D}}
$$

where $D_{\infty}$ is the total infinite plane exposure rate and $D$ is the exposure rate in question.

To accurately determine a protection factor, it is necessary to simulate fallout radiation on the ground surrounding the vehicle out to an infinite distance. Since this is impractical, simulation in these experiments was limited to the immediate vicinity of the vehicles, where results would be helpful in estimating protection factors. The contribution from those areas not simulated was analytically estimated by using experimental data as guide lines.

Type 4106 buses show a range of protection factors from 1.4 to 2.1 , with an average of 1.7 .

Type 4107 buses show a range of protection factors from 1.6 to 1.9 , with an average of 1.7 .

School buses show a range of protection factors from 1.5 to 1.8 , with an average of 1.6 .

These protection factors are expected to be accurate to within a standard deviation of $\pm 6 \%$. The accuracy of the data is within a standard deviation of $\pm 5.3 \%$. The Do was taken as $\pm 3 \%$. (Reference 3 contains a detailed error analysis of a similar experiment.) Very little difference is noted for the abdomen and chest areas. 
Both the measurements and the reference $\left(\mathrm{D}_{\infty}\right)$ were taken above a smooth plane. If both were above a rough plane, which is more realistic, the resulting protection factors would be only slightly different (probably 1.8 instead of 1.7 ).

The difference between fallout protection factors and ${ }^{6 \circ} \mathrm{Co}$ protection factors is negligible for thin shields (as in this experiment). For this reason, the protection offered by these transportation vehicles, as measured in this experiment, can be used for planning possible evacuation of personnel from or through fallout-contamination areas.

\section{REFERENCES}

1. Z. G. Burson, R. L. Summers, and J. T. Brashears, "Mobile Radiological Measuring Unit; Description and Operating Information, "USAEC Report CEX-63.11, February 1965.

2. C. Eisenhauer, Unpublished data presented at the informal session of the Shielding Division at the meeting of the American Nuclear Society in San Diego, California, June 1967.

3. R. L. Summers and Z. G. Burson, "Experimental Evaluation of Techniques for Improving Fallout Protection in Home Basements, "USAEC Report CEX-65.5, December 1966. 


\section{DISTRIBUTION}

EG\&G Las Vegas

Z. G. Burson (6)

G. Felt

E. Matthews

R. A. Shunk

E. J. Story

B. P Warner

EG\&G Santa Barbara

E. F. Blase (2)

$\mathrm{AEC} / \mathrm{DBM}$

I. J. Deal (50)

ALO

D. W. King

NVOO

R. R. Loux

DTIE

W. T. Laughlin 